\title{
Evaluation of mental health and occupational stress in Mexican medical residents
}

\author{
Sofía Vidal de la Fuente, 'Janet Real Ramírez, ${ }^{2}$ Jesús Abrahán Ruíz Rosas, 'Daniela Morera González’
}

Instituto Nacional de Psiquiatría Ramón de la Fuente Muñiz, Ciudad de México, México.

2 Instituto Nacional de Salud Pública, Ciudad de México, México.

\section{Correspondence:}

Daniela Morera González

Instituło Nacional de Psiquiatría

Ramón de la Fuente Muñiz.

Calzada México-Xochimilco 101 ,

Col. San Lorenzo, Huipulco, Tlalpan,

14370, México.

Email: danielamorera@icloud.com

Received: 20 February 2020

Accepted: 8 June 2020

Citation:

Vidal de la Fuente, S. Real Ramírez, J., Ruíz Rosas, J. A., \& Morera González, D. (2019). Evaluation of mental health and occupational stress in Mexican medical residents. Salud Mental, 43(5), 209-218.

DOI: $10.17711 /$ SM. 0185-3325.2020.029

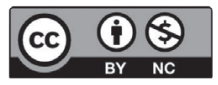

\begin{abstract}
Introduction. Since mental health disorders are an emerging problem in medical residents, its detection and attention must be a priority. Objetive. To compare the frequency of psychopathology in residents according to sociodemographic and clinical characteristics. Method. We conducted a cross-sectional study evaluating the presence of psychopathology, as well as sociodemographic and clinical characteristics in 644 residents through online questionnaires. Results. Among participants, 55.7\% reported a psychiatric disorder at some point and $29.2 \%$ a current one; only $41.5 \%$ were under treatment. Additionally, $8.1 \%$ had attempted suicide, of which $32.4 \%$ attempted it during residency. We found that $6.5 \%$ of women and $3.3 \%$ of men presented "risk of psychopathology," with a higher percentage of men presenting "severe psychopathology." Individuals with "risk of psychopathology" presented significantly higher scores on all of the questionnaires, compared to those with "absence of psychopathology." Discussion and conclusion. Residents with occupational stress also presented higher risks of psychopathology, suicide, and substance use. Being under psychiatric treatment significantly improved the scores on the different scales. Because residency is a period that may increase the probability of suffering psychopathology, interventions should be aimed at reducing occupational stress and bringing specialized care.
\end{abstract}

Keywords: Medical residency, psychopathology, occupational stress, substance use.

\section{RESUMEN}

Introducción. Dado que los trastornos de salud mental son un problema emergente en los médicos residentes, su detección y atención deben ser una prioridad. Objetivo. Comparar la frecuencia de psicopatología en médicos residentes de acuerdo con las características clínicas y sociodemográficas. Método. Realizamos un estudio transversal donde evaluamos la presencia de psicopatología, así como características clínicas y sociodemográficas en 644 médicos residentes por medio de cuestionarios en línea. Resultados. Entre los participantes, el $55.7 \%$ reportó haber tenido un trastorno psiquiátrico en algún momento de su vida y el $29.2 \%$ al momento del estudio, de los cuales solo el $41.5 \%$ estaba bajo tratamiento psiquiátrico. Asimismo, el $8.1 \%$ había intentado suicidarse a lo largo de su vida y el $32.4 \%$ lo intentó durante la residencia. Encontramos que el $6.5 \%$ de las mujeres y el $3.3 \%$ de los hombres presentaban "riesgo de psicopatología", y un mayor porcentaje de hombres presentaron "psicopatología grave". Las personas con "riesgo de psicopatología" contaron con puntuaciones significativamente más altas en todos los cuestionarios, en comparación con los individuos con "ausencia de psicopatología". Discusión y conclusión. Los residentes con estrés laboral también presentaron mayor riesgo de psicopatología, suicidio y uso de sustancias. Estar bajo tratamiento psiquiátrico mejoró significativamente los puntajes en las diferentes escalas. Debido a que la residencia es un período que puede aumentar la probabilidad de sufrir psicopatología, las intervenciones deben estar dirigidas a reducir el estrés ocupacional y brindar atención especializada.

Palabras clave: Residencia médica, psicopatología, estrés laboral, uso de sustancias. 


\section{INTRODUCTION}

Mental health disorders are an emerging problem in resident doctors due to conditions such as stigma, work environment, academic requirements, and the complexity of medical care. Some studies indicate that the prevalence of burnout increases throughout training (Becker, Milad, \& Klock, 2006; Dyrbye et al., 2014; Dyrbye \& Shanafelt, 2016), and may be higher than in other university degrees (Shanafelt, Sinsky, Dyrbye, Trockel, \& West, 2019). Residents are exposed to a high workload, academic pressure, peer competition, discrimination based on sex, age and academic rank, lack of sleep, fatigue, interpersonal conflicts, and inability to meet personal needs; factors that have been associated to occupational stress and the onset of psychiatric disorders (Romo-Nava et al., 2019; Veldenz, Scott, Dennis, Tepas, \& Schinco, 2003).

Some studies have reported a higher prevalence of psychopathology among doctors compared to the general population (Melo-Carrillo, Van Oudenhove, \& Lopez-Avila, 2012; Romo-Nava et al., 2019; Schwenk, Davis, \& Wimsatt, 2010; Dyrbye, Thomas, \& Shanafelt, 2006; Quince, Wood, Parker, \& Benson, 2012), where depression, anxiety (Olagunju, Ogundipe, Lasebikan, Coker, \& Asoegwu, 2016), substance use (Cottler et al., 2013), and suicidal risk prevail (Dutheil et al., 2019). As a consequence, poor academic performance, attrition, deterioration in patient care, and suicide are documented (Coentre \& Figueira, 2015; Coentre, Faravelli, \& Figueira, 2016; Dyrbye et al., 2006; Quince et al., 2012). In medical students and resident physicians, the prevalence of depression and anxiety has a wide range (Jiménez-López, Arenas-Osuna, \& Angeles-Garay, 2015; Melo-Carrillo et al., 2012; Romo-Nava et al., 2019). In the United States, a prevalence of depression of $48.5 \%$ is reported, while in the United Kingdom it goes from 5.7 to $10.6 \%$, depending on the academic year (Romo-Nava et al., 2019). In Mexico, reports in resident medical units range from $25 \%$ to $79.6 \%$ for depression and $39 \%$ to $69.9 \%$ for anxiety, with the highest prevalence in second year residents (Jiménez-López et al., 2015). Likewise, a systematic review that included 17,560 residents, found that $28.8 \%$ had depression (range 20.9\% - 43.2\%) (Mata et al., 2015); while a study published in 2019 reported a prevalence of depression of $16.2 \%$ (Romo-Nava et al., 2019). Among physicians, the life time prevalence of alcohol and illegal drug use shows similar levels to those in the general population (10-12\% versus $7-15 \%$, respectively) (DuPont, McLellan, Carr, Gendel, \& Skipper, 2009; Elliot, Tan, \& Norris, 2010). Among the substances of higher consumption are alcohol, tobacco, and marihuana, followed by prescription drugs such as opiates and benzodiazepines (Martínez-Lanz, Medina-Mora, \& Rivera, 2005). Suicide is a public health problem accountable for many deaths annually worldwide. The suicide rate in doctors, particularly female physicians, is higher than the general population (Center et al., 2003; Gold, Sen,
\& Schwenk, 2013; Jin \& Guo, 2018; Mingote Adan, Crespo Hervás, Hernández Álvarez, Navío, \& García-Pando, 2013). Furthermore, it is considered the only cause of death with higher prevalence among doctors than the general population (A'Brook, Hailstone, \& McLaughlan, 1967; Dutheil et al., 2019). A prevalence of $12 \%$ of suicidal ideation has been reported in residents (van der Heijden, Dillingh, Bakker, \& Prins, 2008; Jiménez-López et al., 2015). Suicide is mostly related to untreated mental disorders, psychosocial stressors, access to prescription substances, and knowledge of their lethal doses (Gold et al., 2013; Jin \& Guo, 2018). The lack of recognition of a mental disorder and the stigma that comes with suffering from it within the medical profession is related to an inaccurate self-diagnosis, self-medication, and lack of attention seeking, leading to further mental health deterioration (A'Brook et al., 1967; Adams, Lee, Pritchard, \& White, 2010; Gold et al., 2013; Hassan, Ahmed, White, \& Galbraith, 2009; Veldenz et al., 2003; White, Shiralkar, Hassan, Galbraith, \& Callaghan, 2006).

Because psychopathology can be disabling and because there is insufficient information on how it personally affects residents and the quality of care provided by them, its detection and attention should be a priority (Hochberg et al., 2013). The aim of this study was to compare the frequency of psychopathology grouped in the categories "absence of psychopathology," "risk of psychopathology," and "severe psychopathology" in medical residents according to sociodemographic and clinical characteristics such as age, marital status, type of specialty, year of residency, institution of origin, medical night shifts frequency, psychiatric history, peer and/or superior discrimination, substance use, suicidal risk, and occupational stress. We hypothesized that residents with occupational stress would also have high frequencies of psychopathology, substance use, and suicidal risk.

\section{METHOD}

\section{Study design}

We conducted a cross-sectional study in which Mexican and foreign resident doctors of any specialty within the units belonging to the Comisión Coordinadora de Institutos Nacionales de Salud y Hospitales de Alta Especialidad (CCINSHAE) during the period of August 2016 to January 2017 were invited to voluntarily participate. Residents received an invitation and access link via email with self-applying questionnaires to assess psychopathology, sociodemographic, and clinical characteristics. Some of the respondents answered the questionnaires partially; we excluded participants who did not complete any of the scales and those who did not accept to participate. The questionnaires were answered once the participant read and accepted the terms of the informed consent, in which the privacy and confidentiality of 
their answers were guaranteed without labor or academic repercussions, as well as the possibility of withdrawing their participation from the study at any time. The platform allowed completing the questionnaires in several attempts. If a participant showed suicide risk scores when answering the questionnaires, guidance was provided through messages on the platform to request immediate psychiatric care.

\section{Measurements}

We included six self-applied instruments:

1. Symptom Check-List-90 Revised (SCL-90r). Includes 90 Likert-type scale items to evaluate psychiatric symptoms. According to the score, it classifies them in three groups: "absence of psychopathology" ( $\leq 65)$, "risk of psychopathology" ( $\geq 66$ to $\leq 79)$, or "severe psychopathology" ( $\geq$ $80)$. It has been used in Mexican population, where seven of the nine dimensions, and the Global Severity Index (GSI) showed good internal consistency (Cronbach's alpha $>.7$ ), while the remaining have scores greater than .6 (Cruz Fuentes, López Bello, Blas García, González Macías, \& Chávez Balderas, 2005).

2. Alcohol Smoking and Substance Involvement Screening Test (ASSIST). It measures consumption and related problems in the last three months and throughout life. It indicates the risk for each substance according to the pattern of use, classifying it as "low" (alcohol score 0-10, other substances 0-3), "moderate" (alcohol score 11-26, other substances 4-26), and "high" (alcohol and other substances score $\geq 27$ ). The self-applicable version is an acceptable, valid, and simple screening instrument. In Mexican population it has had acceptable reliability coefficients for tobacco (alpha $=.83)$, alcohol (alpha $=.76)$, and marijuana (alpha $=.73$ ) subscales. The sensitivity and specificity tests show that by using a rating of 8 as a cut-off point in the alcohol subscale a better balance is obtained between both indicators (83.8\% and $80 \%$, respectively) (Tiburcio Sainz et al., 2016).

3. Plutchik Suicide Risk Scale. A 15-item scale with dichotomous responses. It assesses previous suicide attempts, intensity of current suicidal ideation, feelings of depression and hopelessness, and related factors. It is validated in Spanish, with a proposed cut-off point for suicide risk of 6 or higher; it has an acceptable reliability coefficient (Cronbach's alpha > .7) (Santana-Campas \& Santoyo Telles, 2018).

4. Occupational Stress Instrument for Physicians. It consists of 40 items rated on a Likert-type scale, and assesses emotional wear, job dissatisfaction, equity between effort and compensation, and environmental demands. It is validated in the Mexican population with adequate internal consistency (Cronbach’s alpha = .937) (Hernández González, Ortega Andeane, \& Reidl Martínez, 2012).

5. Additionally, we formulated four questions with dichotomous answers, related to discrimination, physical violence, workplace/academic harassment and/or sexual harassment, by peers and/or superiors (Appendix).

\section{Statistical analysis}

Residents were grouped according to the year of residence at the time of study, as first year (R1), second year (R2), third year (R3), fourth year (R4), and fifth year of residence or higher ( $\geq$ R5). Medical specialties were grouped by academic requirement in: "Clinical," "Surgical," and "Preventive Medicine, Diagnosis and Public Health." We also grouped participants according to the frequency of medical night shifts in $\mathrm{ABC}$ ( $\geq 80$ working hours per week) or ABCD ( $\leq 79$ working hours per week). According to the scores on the SCL-90-r, residents were categorized in "absence of psychopathology," "risk of psychopathology," or "severe psychopathology," and, based on these categories, differences were sought among the Occupational Stress Scale, ASSIST, Plutchik Suicide Risk Scale, and peer/superior discrimination, as well as clinical and demographic variables.

Because not all participants completed the totality of the scales, different samples were obtained and analyzed independently per instrument. If a scale was partially completed, that participant was not considered in the analysis of that specific scale. A descriptive analysis was carried out with frequencies and measures of central tendency. Parametric and non-parametric tests were used according to the distribution of the analysis subsamples: $\chi^{2}$, Fisher, Student $T$, and ANOVA tests, as well as a Tukey subanalysis as a test of means contrast between groups. The statistical package SPSS version 15 was used.

\section{Ethical considerations}

Our study was approved by the Ethics Committee of the Instituto Nacional de Psiquiatría Ramón de la Fuente Muñiz, in Mexico City. We were committed to the Declaration of Helsinki and ethical rules of our country throughout the study. Participants did not receive any compensation.

\section{RESULTS}

From 3795 medical residents of fifteen specialized medical institutions, three general hospitals, and five regional spe- 
Table 1

Sociodemographic and clinical characteristics of the study population

\begin{tabular}{|c|c|c|c|c|}
\hline & $\begin{array}{c}\text { Total } \\
N=644 \\
n(\%)\end{array}$ & $\begin{array}{c}\text { Male } \\
n=279 \\
n(\%)\end{array}$ & $\begin{array}{c}\text { Female } \\
n=365 \\
n(\%)\end{array}$ & $p^{*}$ \\
\hline \multicolumn{5}{|l|}{$\overline{\text { Age }}$} \\
\hline$\geq 28$ years & $465(72.2)$ & $197(30.6)$ & $268(41.6)$ & .429 \\
\hline$\leq 27$ years & $179(27.8)$ & $82(12.7)$ & $97(15.1)$ & \\
\hline \multicolumn{5}{|l|}{ Marital status } \\
\hline With formal partner & $352(54.7)$ & $151(23.4)$ & $201(31.4)$ & .81 \\
\hline No formal partner & $292(45.3)$ & $128(19.9)$ & $164(25.6)$ & \\
\hline \multicolumn{5}{|l|}{ Type of specialty } \\
\hline Clinic & $406(63.0)$ & $171(26.6)$ & $235(36.5)$ & .092 \\
\hline Surgical & $151(23.4)$ & $76(11.8)$ & $75(11.6)$ & \\
\hline $\begin{array}{l}\text { Preventive, Diag- } \\
\text { nosis and Public } \\
\text { Health }\end{array}$ & $87(13.5)$ & $32(5.0)$ & $55(8.5)$ & \\
\hline \multicolumn{5}{|l|}{ Year of residency } \\
\hline $\mathrm{R} 1$ & $152(23.6)$ & $67(10.4)$ & $85(13.2)$ & .054 \\
\hline $\mathrm{R} 2$ & $110(17.1)$ & $47(7.3)$ & $63(9.8)$ & \\
\hline R3 & $111(17.2)$ & $52(8.1)$ & $59(9.2)$ & \\
\hline $\mathrm{R} 4$ & $129(20.0)$ & $42(6.5)$ & $87(13.5)$ & \\
\hline R5 or greater & $142(22.0)$ & $71(11.0)$ & $71(11.0)$ & \\
\hline \multicolumn{5}{|l|}{ Medical night shifts } \\
\hline$\geq \mathrm{ABCD}$ & $347(54.0)$ & $141(21.9)$ & $207(32.0)$ & .823 \\
\hline$\leq \mathrm{ABC}$ & $296(46.0)$ & $138(21.5)$ & $158(24.6)$ & \\
\hline \multicolumn{5}{|l|}{$\begin{array}{l}\text { History of psychiatric } \\
\text { disorder }\end{array}$} \\
\hline No & $286(44.4)$ & $141(21.9)$ & $145(22.5)$ & .006 \\
\hline Yes & $358(55.6)$ & $138(21.4)$ & $220(34.2)$ & \\
\hline $\begin{array}{l}\text { History of psychiatric } \\
\text { treatment }\end{array}$ & $n=358$ & $n=138$ & $n=220$ & \\
\hline No & $155(43.3)$ & $72(20.1)$ & $83(23.2)$ & $>0.000$ \\
\hline Yes & $203(56.7)$ & $66(18.4)$ & $137(38.3)$ & \\
\hline $\begin{array}{l}\text { Current psychiatric } \\
\text { disorder }\end{array}$ & $n=644$ & $n=279$ & $n=365$ & \\
\hline No & $456(70.8)$ & $220(34.2)$ & $236(36.6)$ & $<0.000$ \\
\hline Yes & $188(29.2)$ & $59(9.2)$ & $129(20.0)$ & \\
\hline $\begin{array}{l}\text { Current psychiatric } \\
\text { treatment }\end{array}$ & $n=188$ & $n=59$ & $n=129$ & \\
\hline No & $110(58.5)$ & $32(17.0)$ & $78(41.5)$ & .847 \\
\hline Yes & $78(41.5)$ & $27(14.4)$ & $51(27.1)$ & \\
\hline $\begin{array}{l}\text { Previous suicide } \\
\text { attempts }\end{array}$ & $n=644$ & $n=279$ & $n=365$ & \\
\hline No & $592(91.9)$ & $265(41.1)$ & $327(50.8)$ & .029 \\
\hline Yes & $52(8.1)$ & $14(2.2)$ & $38(5.9)$ & \\
\hline $\begin{array}{l}\text { Suicide attempts } \\
\text { during residency }\end{array}$ & $n=34$ & $n=9$ & $n=25$ & \\
\hline No & $23(67.6)$ & $6(17.6)$ & $17(50.0)$ & .83 \\
\hline Yes & $11(32.4)$ & $3(8.8)$ & $8(23.5)$ & \\
\hline Current suicide risk & $n=443$ & $n=164$ & $n=279$ & \\
\hline No & $360(81.3)$ & $140(31.6)$ & $220(49.7)$ & .09 \\
\hline Yes & $83(18.7)$ & $24(5.4)$ & 59 (13.3) & \\
\hline
\end{tabular}

${ }^{*}$ Chi2 test. cialized hospitals, a total of 644 participated, representing a response rate of $17 \%$. The distribution by sex was $56.6 \%$ $(n=365)$ women and $43.3 \%(n=279)$ men. The average age among respondents was 29 (range 24 - 48). Participants were distributed according to age and year of residency; we found that most residents 27 years and younger were first and second year students, while those aged 28 years and older were in their third and fourth year of residency. Of all residents, $46.1 \%(\mathrm{R}=297)$ reported "ABC" medical night shifts at the time of the study.

Among participants, $55.6 \%(n=358)$ reported a previous psychiatric disorder, and $29.2 \%(n=188)$ a current one; of this last group, only $41.5 \%(n=78)$ was under treatment; $8.1 \%(n=52)$ reported a history of suicide attempt, of which $32.4 \%(n=11)$ attempted it during residency. Previous psychiatric disorders, and treatments, current psychiatric disorders, and suicide attempts were more frequent in women (Table 1).

\section{Psychopathology Assessment (SCL-90-r)}

Among 90.2\% $(n=581)$ of the residents who completed the SCL-90-r questionnaire, $37.2 \%(n=216)$ men and $49.9 \%$ $(n=290)$ women presented "absence of psychopathology;" $6.5 \%(n=38)$ women and 3.3\% $(n=19)$ men presented "risk of psychopathology;" despite the higher frequency of psychopathology risk in women, a higher percentage of men, 2.2\% $(n=13)$ versus .9\% $(n=5)$, presented "severe psychopathology." We found no statistically significant differences regarding the risk of psychopathology with other sociodemographic variables (Table 2).

When comparing the risk of psychopathology with the different scales, individuals with "risk of psychopathology" and "severe psychopathology" presented significantly higher scores on the Occupational Stress Scale $(p<.000)$, ASSIST $(p<.000)$ and Suicidal Risk Scale $(p<.000)$, compared to those with "absence of psychopathology" (Table 3).

\section{Suicide Risk Assessment (Plutchik Suicide Risk Scale)}

Of the total residents who completed the Suicide Risk Scale $(n=443), 18.7 \%(n=83)$ presented suicide risk at the time of the study. Residents that reported peer/superior discrimination, prior psychiatric disorders and treatment, previous suicide attempts, and current psychiatric disorders, as well as those who had moderate or high risk of using alcohol, amphetamines, tranquilizers, and "other" substances also presented "suicide risk" significantly more frequently than those without these characteristics (Table 4). When compared with fourth year residents (1.5-2.8 points), third year students presented significantly higher scores on the suicide risk scale (3.3-3.9 points; $p=.006)$. 
Table 2

Categories of psychopathology (SCL-90R) according to sociodemographic and clinical characteristics

\begin{tabular}{|c|c|c|c|c|c|c|c|c|}
\hline \multirow[b]{3}{*}{ Sex } & \multirow{3}{*}{$\frac{\text { Total }}{n}$} & \multirow{2}{*}{\multicolumn{2}{|c|}{$\begin{array}{c}\begin{array}{c}\text { Absence of } \\
\text { psychopathology }\end{array} \\
n(\%)\end{array}$}} & \multirow{2}{*}{\multicolumn{2}{|c|}{$\begin{array}{c}\begin{array}{c}\text { Psychopathology } \\
\text { risk }\end{array} \\
n(\%)\end{array}$}} & \multirow{2}{*}{\multicolumn{2}{|c|}{$\begin{array}{c}\text { Severe } \\
\text { psychopathology } \\
n(\%)\end{array}$}} & \multirow{3}{*}{$p^{*}$} \\
\hline & & & & & & & & \\
\hline & & 506 & $(87.0)$ & 57 & $(9.8)$ & 18 & (3.1) & \\
\hline Male & 248 & 216 & (37.1) & 19 & (3.2) & 13 & $(2.2)$ & .015 \\
\hline Female & 333 & 290 & (49.9) & 38 & (6.5) & 5 & $(.8)$ & \\
\hline Age & 581 & 506 & $(87.1)$ & 57 & (9.8) & 18 & (3.1) & \\
\hline$\geq 28$ years & 425 & 376 & $(64.7)$ & 36 & $(6.2)$ & 13 & $(2.2)$ & .197 \\
\hline$\leq 27$ years & 156 & 130 & $(22.4)$ & 21 & (3.6) & 5 & $(.9)$ & \\
\hline Current suicide risk & 443 & 372 & $(84.0)$ & 53 & $(12.0)$ & 18 & (4.1) & \\
\hline Suicide risk & 83 & 36 & (8.1) & 29 & (6.5) & 18 & $(4.1)$ & $<.000$ \\
\hline No Suicide risk & 360 & 336 & $(75.8)$ & 24 & (5.4) & 0 & $(.0)$ & \\
\hline Peer discrimination & 566 & 492 & $(86.9)$ & 56 & (9.9) & 18 & (3.2) & \\
\hline With discrimination & 190 & 149 & $(26.3)$ & 26 & $(4.6)$ & 15 & (2.7) & $<.000$ \\
\hline Absence of discrimination & 376 & 343 & $(60.6)$ & 30 & $(5.3)$ & 3 & $(.5)$ & \\
\hline Superior discrimination & 566 & 492 & $(86.9)$ & 56 & $(9.9)$ & 18 & (3.2) & \\
\hline With discrimination & 226 & 179 & $(31.6)$ & 33 & $(5.8)$ & 14 & $(2.5)$ & $<.000$ \\
\hline Absence of discrimination & 340 & 313 & $(55.3)$ & 23 & $(4.1)$ & 4 & $(.7)$ & \\
\hline
\end{tabular}

\section{Occupational Stress Assessment (Occupational Stress Scale)}

Women obtained significantly higher scores on the Occupational Stress Assessment compared to men $(49.0 \pm 31.7$ vs $36.0 \pm 32.2 ; p<.005)$. Likewise, participants who reported peer/superior discrimination, previous suicide attempts, previous psychiatric disorders and treatment, current psychiatric disorders, and suicidal risk, as well as residents with moderate or high risk of consumption of tobacco, alcohol, cannabis, cocaine, amphetamines, and tranquilizers had significantly higher scores on this scale than those without these characteristics. Second-year residents also obtained significantly higher total scores ( $50.5 \pm 32.8$ points $)$, compared to fourth-year residents ( $37.4 \pm 32.0$ points; $p=.032$ ).

The group with the highest scores was the "Clinical" specialties group $(46.9 \pm 31.8$ points $)$, with statistically significant differences in relation to the "Surgical" group (36.97 \pm 33.44 points; $p=.004)$ (Table 5).

\section{Substance Use Assessment (ASSIST)}

Women presented more frequently "moderate risk" of alcohol $(p=.029)$ and "other" substances use $(p=.012)$ com-

Table 3

Categories of psyhcopathology (SCL-90R) according to Occupational Stress Scale, AS-SIST, and Plutchick Suicide Risk Scale Scores

\begin{tabular}{lrrccc}
\hline & $n$ & Mean & $S D(95 \% \mathrm{Cl})$ & $p^{*}$ \\
\hline Occupational Stress Scale & & & & \\
$\quad$ Absence of psychopathology & 493 & 36.9 & $28.7[34.3,39.4]$ & $<.000$ \\
Psychopathology risk & 57 & 80.4 & $22.7[74.3,86.4]$ & \\
$\quad$ Severe psychopathology & 18 & 102.7 & $13.4[96.1,109.4]$ & \\
ASSIST & & & & \\
Absence of psychopathology & 503 & 18.4 & $15.5[17.0,19.8]$ & $<.000$ \\
Psychopathology risk & 56 & 31.5 & $22.5[25.5,37.6]$ & \\
$\quad$ Severe psychopathology & 18 & 40.7 & $25.1[28.2,53.2]$ & \\
Plutchik Suicide Risk Scale & & & & \\
$\quad$ Absence of psychopathology & 372 & 1.6 & $2.6[1.3,1.8]$ & $<.000$ \\
Psychopathology risk & 53 & 6 & $3.1[5.1,6.8]$ & \\
$\quad$ Severe psychopathology & 18 & 9.3 & $2.6[8.0,10.7]$ & \\
\hline
\end{tabular}

*ANOVA. 
Table 4

Suicide risk according to clinical and sociodemographic characteristics

\begin{tabular}{|c|c|c|c|c|c|c|}
\hline & \multirow[b]{2}{*}{$N$} & \multicolumn{2}{|c|}{ No suicide risk } & \multicolumn{2}{|c|}{ Suicide risk } & \multirow[b]{2}{*}{$p^{a}$} \\
\hline & & $n$ & $\%$ & $n$ & $\%$ & \\
\hline Medical night shifts & 443 & 360 & 81.3 & 83 & 18.7 & .429 \\
\hline$\geq \mathrm{ABCD}$ & 191 & 152 & 34.3 & 39 & 8.8 & \\
\hline Type of specialty & 443 & 360 & 81.3 & 83 & 18.7 & .106 \\
\hline Preventive, Diagnosis and Public Health & 67 & 55 & 12.4 & 12 & 2.7 & \\
\hline Year of residency & 443 & 360 & 81.3 & 83 & 18.7 & .198 \\
\hline R1 & 102 & 88 & 19.9 & 14 & 3.2 & \\
\hline $\mathrm{R} 2$ & 75 & 59 & 13.3 & 16 & 3.6 & \\
\hline R3 & 78 & 58 & 13.1 & 20 & 4.5 & \\
\hline R4 & 92 & 79 & 17.8 & 13 & 2.9 & \\
\hline Superior discrimination & 443 & 360 & 81.3 & 83 & 18.7 & $<.000$ \\
\hline No & 260 & 227 & 51.2 & 33 & 7.4 & \\
\hline Yes & 183 & 133 & 30.0 & 50 & 11.3 & \\
\hline History of psychiatric disorder & 443 & 360 & 81.3 & 83 & 18.7 & $<.000$ \\
\hline No & 183 & 178 & 40.2 & 5 & 1.1 & \\
\hline Yes & 260 & 182 & 41.1 & 78 & 17.6 & \\
\hline History of psychiatric treatment & 443 & 360 & 81.3 & 83 & 18.7 & \\
\hline No & 296 & 266 & 60.0 & 30 & 6.8 & \\
\hline Yes & 147 & 94 & 21.2 & 53 & 12.0 & $<.000$ \\
\hline Previous suicide attempts & 443 & 360 & 81.3 & 83 & 18.7 & $<.000$ \\
\hline No & 392 & 339 & 76.5 & 53 & 12.0 & \\
\hline Current psychiatric treatment & 443 & 360 & 81.3 & 83 & 18.7 & .432 \\
\hline No & 395 & 323 & 72.9 & 72 & 16.3 & \\
\hline Yes & 48 & 37 & 8.4 & 11 & 2.5 & \\
\hline Tobacco & 441 & 359 & 81.4 & 82 & 18.6 & .240 \\
\hline Low risk & 262 & 218 & 49.4 & 44 & 10.0 & \\
\hline Moderate-High risk & 179 & 141 & 32.0 & 38 & 8.6 & \\
\hline Alcohol & 441 & 359 & 81.4 & 82 & 18.6 & .047 \\
\hline Low risk & 84 & 62 & 14.1 & 22 & 5.0 & \\
\hline Moderate-High risk & 357 & 297 & 67.3 & 60 & 13.6 & \\
\hline Cannabis & 441 & 359 & 81.4 & 82 & 18.6 & .127 \\
\hline Low risk & 369 & 305 & 69.2 & 64 & 14.5 & \\
\hline Moderate-High risk & 72 & 54 & 12.2 & 18 & 4.1 & \\
\hline Cocaine & 441 & 359 & 81.4 & 82 & 18.6 & $.249^{b}$ \\
\hline Low risk & 429 & 351 & 79.6 & 78 & 17.7 & \\
\hline Moderate-High risk & 12 & 8 & 1.8 & 4 & .9 & \\
\hline Anphetamines & 441 & 359 & 81.4 & 82 & 18.6 & $<.000$ \\
\hline Inhalants & 441 & 359 & 81.4 & 82 & 18.6 & $.310^{\mathrm{b}}$ \\
\hline Low risk & 435 & 355 & 80.5 & 80 & 18.1 & \\
\hline Moderate-High risk & 6 & 4 & .9 & 2 & .5 & \\
\hline Tranquilizers & 441 & 359 & 81.4 & 82 & 18.6 & $<.000$ \\
\hline Low risk & 357 & 309 & 70.1 & 48 & 10.9 & \\
\hline Moderate-High risk & 84 & 50 & 11.3 & 34 & 7.7 & \\
\hline
\end{tabular}

a Chi2 test, b Fisher's exact test. 
Table 5

Occupational Stress Scale Scores according to the year of residency and type of specialty

\begin{tabular}{|c|c|c|c|c|}
\hline & $n$ & Mean & $S D(95 \% C l)$ & $p^{*}$ \\
\hline \multicolumn{5}{|l|}{ Year of residency } \\
\hline $\mathrm{R} 1$ & 134 & 43.8 & $30.2[38.6,49.0]$ & .032 \\
\hline $\mathrm{R} 2$ & 99 & 50.5 & $32.8[44.0,57.1]$ & \\
\hline R3 & 100 & 46.5 & $32.6[40.0,53.0]$ & \\
\hline $\mathrm{R} 4$ & 112 & 37.4 & $32.0[31.4,43.4]$ & \\
\hline R5 & 125 & 40.3 & $34.3[34.3,46.4]$ & \\
\hline \multicolumn{5}{|l|}{ Type of specialty } \\
\hline $\begin{array}{l}\text { Preventive medicine, } \\
\text { Diagnosis and Public } \\
\text { Health }\end{array}$ & 80 & 38.5 & $32.8[31.2,45.8]$ & .004 \\
\hline Surgical & 131 & 36.9 & $33.4[31.1,42.7]$ & \\
\hline Clinical & 359 & 46.9 & $31.7[43.6,50.2]$ & \\
\hline
\end{tabular}

*ANOVA.

pared to men. We found significantly higher scores in the ASSIST among individuals with peer/superior discrimination, current suicidal risk, previous psychiatric disorder and treatment, and current psychiatric disorder.

Of the study group, 90.2\% $(n=581)$ responded the ASSIST, of which $35.4 \%(n=206)$ presented "moderate risk" and 2.4\% $(n=14)$ "high risk" of tobacco use, and $64 \%(n=372)$ "moderate risk" and 2.2\% $(n=13)$ "high risk" of alcohol use. Regarding the use by type of substance, "moderate risk" was reported in 14.1\% $(n=82)$ for cannabis, $2.2 \%(n=13)$ for cocaine, $10.5 \%(n=61)$ for amphetamines, $15.8 \%(n=92)$ for tranquilizers, $1.2 \%$ $(n=7)$ for inhalants, $3.6 \%(n=21)$ for hallucinogens, $2.4 \%$ ( $n=14$ ) for opiates, and $1.5 \%(n=9)$ for "other" substances; and $0.5 \%(n=3)$ reported having used injectable substances.

\section{Peer and Superior Discrimination Assessment}

We found that medical residents who reported peer/superior discrimination had significantly higher scores in the SCL90-r, ASSIST, Occupational Stress and Plutchik Suicide Risk scales.

\section{DISCUSSION AND CONCLUSION}

Resident doctors, unlike other professions, face innumerable stressors. In addition to the job structure, the nature of medical profession implies stressors like patient death and suffering, as well as difficulty in work-life balance, considered as contributing factors of occupational stress, which leads to a poor well-being, health problems (e.g., increased blood lipids and sugar levels as well as suppression of immune function), and a higher risk of psychopathology in this group around the world (Dyrbye et al., 2014; Wang, Ren,
Tian, Tang, \& Meng, 2019). In response to the high prevalence of burnout and other forms of distress, some medical schools are required to have student wellness programs, and several countries have modified their laws to limit working hours to 56-72 hours per week in their university specialization courses (Prieto-Miranda, Jiménez-Bernardino, Cázares-Ramírez, Vera-Haro, \& Esparza-Pérez, 2015). At the time of the study, $52.3 \%$ and $36 \%$ of the residents worked approximately three and four night shifts per week, respectively; this translates into being subjected to 75 to 96 hours of weekly service, which implies a serious health risk and has been related to progressive loss of energy and symptoms of anxiety and depression, leading to a higher risk of error, injuries, and accidents, as well as deterioration in the quality of patient care (Caruso, 2014).

In the study group, we found high levels of occupational stress among individuals with "risk of psychopathology" and "severe psychopathology." Furthermore, most individuals with "risk of psychopathology" and "severe psychopathology" had significantly higher scores on the ASSIST and Plutchik Suicide Risk Scales, suggesting the possibility of a relationship between psychopathology with substance use and suicide risk.

The finding that $8 \%$ of the individuals with "absence of psychopathology" presented suicide risk is in line with the literature stating that not all who present suicide risk must have a psychiatric illness, but rather could also be associated with factors such as job problems or a crisis in a work situation and the inability to cope with them (Brooks, Gendel, Early, \& Gundersen, 2018; Gold et al., 2013; Mingote Adan et al., 2013).

Of all participants, $55.6 \%$ referred subjectively to having suffered a mental disorder at some point in their life, a difference of 27 percentage points with respect to the general population (Steel et al., 2014). We found that residents with a history of psychiatric disorders scored higher on the scales of occupational stress and psychopathology. Likewise, women presented a higher frequency of history of psychiatric disorders, occupational stress, and risk of psychopathology, information which matches that of the literature (Afifi, 2007; Boyd et al., 2015). On the other hand, according to SCL-90-r, $12.9 \%$ of the participants presented risk of psychopathology and severe psychopathology; the highest frequency of severe psychopathology occurred in men. These data support the susceptibility to suffer a psychiatric disorder in residents (Brooks, Chalder, \& Gerada, 2011). Because psychiatric illnesses are treatable, and because doctors should be the first to reduce stigma towards mental disorders, this situation should never condition the admission or permanence in the medical residency, but promote the development of preventive interventions and psychological support to the residents, and the existence of healthy learning environments that protects them and prioritizes their medical care. 
According to the type of medical specialty, we found no statistically significant difference in the risk of psychopathology. In contrast, Jiménez López et al. (2015) reported more depression and anxiety symptoms, as well as a greater suicide risk in Pathology, Urology and Internal Medicine medical residents. This difference could be explained by the fact that the results of this study have low external validity due to the marked differences of sub-populations in each medical specialty group, where $13.9 \%$ of the evaluated sample was studying some type of diagnostic, public health and preventive specialties; $23.1 \%$ surgical specialties; and $63 \%$ clinical specialties.

The finding that second year residents had higher scores on the psychopathology and occupational stress scales could be attributed to inequitable and risky workloads in this group, conditioned by peer power relationships. These data forces us to redirect efforts to reorganize operational academic services and programs and coincides with previous reports (Australian Medical Association, 2011). Likewise, the finding that individuals who reported discrimination by peers and/or superiors also had higher scores on occupational stress and psychopathology scales supports the urgency to address modifiable variables to generate work environments that favor the good professional performance of doctors.

According to the Instituto Nacional de Estadística y Geografía (2019), in Mexico suicide is the first cause of mortality among psychiatric disorders, being more frequent in men (8.6 against 1.9 in women per 100000 inhabitants). Mingote Adan et al. (2013) reported that, among doctors, suicide was the only cause of death with greater prevalence than in general population. In this study we found that $18.7 \%$ of the residents had risk of suicide, $8.1 \%$ had a history of a suicide attempt, and of these, $32.5 \%$ attempted suicide during residency. The reduction of occupational stress, in addition to the diagnosis and treatment of mental disorders, are scientifically proven, immediate, and effective measures to prevent suicide (Dutheil et al., 2019; Dyrbye et al., 2008).

We found moderate to high risk of consumption of the following substances in order of frequency: alcohol, tobacco, tranquilizers, and cannabis, information that coincides with the literatura. Despite the low use of opiates in this study group, there is a percentage of residents with moderate risk of consumption. In accordance with what was reported by Reséndiz Escobar et al. (2018) regarding the increase of substance use in women, our study documented a greater number of female residents with moderate risk of alcohol and other substances use compared to men. Due to the relationship between psychopathology and substance use, this finding could be related to the presence of a higher "risk of psychopathology" in the female gender.

Psychopathology, suicide risk, and substance use are widely preventable and treatable conditions (Hochberg et al., 2013). The attention of residents with psychopathology is conditioned by the social stigma among the same medical union that demerits those who suffer from them and contributes to the delay in seeking for medical care. In the present study we found that individuals under psychiatric treatment had significantly lower scores on all of the applied scales, therefore, providing timely and adequate treatment could contribute to reduce occupational stress, suicide risk, substance use, and psychopathology in resident doctors. According to international experience, having specialized mental health centers for doctors, in which the confidentiality and protection of information are a fundamental priority, facilitates the acceptance, treatment seeking, and reinstatement of those suffering from a mental disorder (Elliot et al., 2010). Reducing occupational stress, making timely diagnoses, and providing an appropriate treatment for mental disorders are preventive, immediate, and widely effective measures.

In the case of this and other studies, the use of online questionnaires and guaranteeing participants confidentiality, favor a greater participation of residents, an instant record of results, a quick analysis of the information, and low monetary costs. Furthermore, there is evidence that the anonymity of responses and the access to care without repercussions in their work environment may be useful to seek and accept treatment (Nayak \& Narayan, 2019).

This study has some limitations. It is not possible to establish causal relationships due to the transversal design; nor was it possible to compare self-assessment inventories with the gold standard of clinical interviews. The response rate in our study was less than $20 \%$; a non-response bias is common on online survey research since most people tend to ignore these requests, and there may also be long delays, up to months, in respondents' completing the survey. We also have to consider that these results represent only those who decided to participate, which raises the possibility of greater interest from individuals at higher risk of psychopathology and therefore greater need for help. Furthermore, the results should be taken with caution because we limited the study to residents belonging to institutions affiliated to the CCINSHAE. Therefore, the participants represent a specific population of the resident medical system in Mexico. Future studies that include longitudinal designs, multivariate analyses, controlling for potential confounders of psychopathology risk, such as family history of psychiatric disorders, environmental factors, sleep deprivation, and eating habits, and that involve residents of all institutions responsible for medical training in our country are necessary.

In the sample evaluated, we observed that approximately half of the residents had a history of psychiatric disorders. Individuals with occupational stress also presented an increased risk of psychopathology and suicide. Furthermore, it should be emphasized that the suicide risk in this sample was significantly higher than in general population. Importantly, it was documented that individuals under psychiatric treatment had significantly lower scores on all of the applied scales. 
The present data suggest that residency is a period that increases the probability of presenting psychopathology and that interventions should be aimed at reducing occupational stress and, if necessary, offering early specialized care. Doctors, like all professionals, are humans with human needs. Until we promote role models who prioritize physical and mental well-being, rather than complete self-sacrifice, our profession will continue to be afflicted by occupational stress, depression, and suicide.

\section{Funding}

None.

\section{Conflicts of interest}

The authors declare they have no conflicts of interest.

\section{Acknowledgements}

We thank María Elena Medina Mora, Tecelli Domínguez, and José Cortés, investigators who kindly collaborated with the statistical analysis; as well as Karla Vanessa García for her assistance in data acquisition.

\section{REFERENCES}

A'Brook, M. F., Hailstone, J. D., \& McLauchlan, I. E. (1967). Psychiatric illness in the medical profession. The British Journal of Psychiatry, 113(502), 1013-1023. doi: 10.1192/bjp.113.502.1013

Adams, E. F., Lee, A. J., Pritchard, C. W., \& White, R. J. (2010). What stops us from healing the healers: a survey of help-seeking behaviour, stigmatisation and depression within the medical profession. International Journal of Social Psychiatry, 56(4), 359-370. doi: 10.1177/0020764008099123

Afifi M. (2007). Gender differences in mental health. Singapore Medical Journal, 48(5), 385-391.

Australian Medical Association. (2011). Health and wellbeing of doctors and medical students - 2011. Canberra: AMA. Retrieved from https://ama.com.au/positionstatement/health-and-wellbeing-doctors-and-medical-students-2011

Becker, J. L., Milad, M. P., \& Klock, S. C. (2006). Burnout, depression, and career satisfaction: Cross-sectional study of obstetrics and gynecology residents. American Journal of Obstetrics and Gynecology, 195(5), 1444-1449. doi: 10.1016/j.ajog.2006.06.075

Boyd, A., Van de Velde, S., Vilagut, G., de Graaf, R., O’Neill, S., Florescu, S., Alonso, J., \& Kovess-Masfety, V. (2015). Gender differences in mental disorders and suicidality in Europe: Results from a large cross-sectional populationbased study. Journal of Affective Disorders, 173, 245-254. doi: 10.1016/j. jad.2014.11.002

Brooks, E., Gendel, M. H., Early, S. R., \& Gundersen, D. C. (2018) When doctors struggle: Current stressors and evaluation recommendations for physicians contemplating suicide. Archives of Suicide Research, 22(4), 519-528. doi: 10.1080/13811118.2017.1372827

Brooks, S. K., Chalder, T., \& Gerada, C. (2011). Doctors vulnerable to psychological distress and addictions: Treatment from the Practitioner Health Programme. Journal of Mental Health, 20(2), 157-164. doi: 10.3109/09638237.2011.556168

Caruso, C. C. (2014). Negative impacts of shiftwork and long work hours. Rehabilitation Nursing, 39(1), 16-25. doi: 10.1002/rnj.107

Center, C., Davis, M., Detre, T., Ford, D. E., Hansbrough, W., Hendin, H., ... Silverman, M. M. (2003). Confronting depression and suicide in physicians: A consensus statement. JAMA, 289(23), 3161-3166. doi: 10.1001/jama.289.23.3161

Coentre, R., \& Figueira, M. L. (2015) Depression and suicidal behavior in medical students: A systematic review. Current Psychiatry Reviews, 11(2), 86-101. doi: 10.2174/1573400510666140807005141

Coentre, R., Faravelli, C., \& Figueira, M. L. (2016). Assessment of depression and suicidal behaviour among medical students in Portugal. International Journal of Medical Education, 7, 354-363. doi: 10.5116/ijme.57f8.c468
Cottler, L. B., Ajinkya, S., Merlo, L. J., Nixon, S. J., Ben Abdallah, A., \& Gold, M. S. (2013). Lifetime psychiatric and substance use disorders among impaired physicians in a physicians health program: Comparison to a general treatment population: Psychopathology of impaired physicians. Journal of Addiction Medicine, 7(2), 108-112. doi: 10.1097/ADM.0b013e31827fadc9

Cruz Fuentes, C. S., López Bello, L., Blas García, C., González Macías, L., \& Chávez Balderas, R. A. (2005). Datos sobre la validez y confiabilidad de la Symptom Check List 90 (SCL 90) en una muestra de sujetos mexicanos. Salud Mental, 28(1), 72-81.

DuPont, R. L., McLellan, A. T., Carr, G., Gendel, M., \& Skipper, G. E. (2009). How are addicted physicians treated? A national survey of physician health programs. Journal of Substance Abuse Treatment, 37(1), 1-7. doi: 10.1016/j.jsat.2009.03.010

Dutheil, F., Aubert, C., Pereira, B., Dambrun, M., Moustafa, F., Mermillod, M., ... Navel, V. (2019). Suicide among physicians and health-care workers: A systematic review and meta-analysis. PloS One, 14(12), e0226361. doi: 10.1371/journal.pone.0226361

Dyrbye, L. N., Thomas, M. R., \& Shanafelt, T. D. (2006). Systematic review of depression, anxiety, and other indicators of psychological distress among U.S. and Canadian medical students. Academic Medicine, 81(4), 354-373. doi: 10.1097/00001888-200604000-00009

Dyrbye, L. N., Thomas, M. R., Massie, F. S., Power, D. V., Eacker, A., Harper, W., ... Shanafelt, T. D. (2008). Burnout and suicidal ideation among U.S. medical students. Annals of Internal Medicine, 149(5), 334-341. doi: 10.7326/00034819-149-5-200809020-00008

Dyrbye, L. N., West, C. P., Satele, D., Boone, S., Tan, L., Sloan, J., \& Shanafelt, T. D. (2014). Burnout among U.S. medical students, residents, and early career physicians relative to the general U.S. population. Academic Medicine, 89(3), 443-451. doi: 10.1097/ACM.0000000000000134

Dyrbye, L., \& Shanafelt, T. (2016). A narrative review on burnout experienced by medical students and residents. Medical Education, 50(1), 132-149. doi: 10.1111/medu. 12927

Elliot, L., Tan, J., \& Norris, S. (2010). The mental health of doctors: A systematic literature review. Australia: Beyond Blue. Retrieved from http://resources. beyondblue.org.au/prism/file?token=BL/0823

Gold, K. J., Sen, A., \& Schwenk, T. L. (2013). Details on suicide among US physicians: data from the National Violent Death Reporting System. General Hospital Psychiatry, 35(1), 45-49. doi: 10.1016/j.genhosppsych.2012.08.005

Hassan, T. M., Ahmed, S. O., White, A. C., \& Galbraith, N. (2009). A postal survey of doctors' attitudes to becoming mentally ill. Clinical Medicine, 9(4), 327-332. doi: 10.7861/clinmedicine.9-4-327

Hernández González, A. I., Ortega Andeane, R. P., \& Reidl Martínez, L. M. (2012). Validación del Instrumento de Estrés Laboral para Médicos Mexicanos. EnClaves del Pensamiento, 6(11), 113-129. Retrieved from http://www.redalyc. org/articulo.oa?id=141125357007

Hochberg, M. S., Berman, R. S., Kalet, A. L., Zabar, S. R., Gillespie, C., \& Pachter, H. L. (2013). The stress of residency: recognizing the signs of depression and suicide in you and your fellow residents. American Journal of Surgery, 205(2), 141-146. doi: 10.1016/j.amjsurg.2012.08.003

Instituto Nacional de Estadística y Geografía. (2019). Estadísticas a propósito del día mundial para la prevención del suicidio (10 de septiembre de 2019). Comunicado de prensa Num. 455/19. Mexico: INEGI. Retrieved from https://www.inegi.org. $\mathrm{mx} /$ contenidos/saladeprensa/aproposito/2019/suicidios2019_Nal.docx

Jiménez-López, J. L., Arenas-Osuna, J., \& Angeles-Garay, U. (2015). Síntomas de depresión, ansiedad y riesgo de suicidio en médicos residentes durante un año académico. Revista Médica del Instituto Mexicano del Seguro Social, 53(1), 2028. Retrieved from http://www.ncbi.nlm.nih.gov/pubmed/25680640

Jin, H. M., \& Guo, L. L. (2018). Suicide in Medical Doctors: A Review from Mainland China, 2008-2016. Neuropsychiatry, 8(3), 970-976. Retrieved from http://www.jneuropsychiatry.org/peer-review/suicide-in-medical-doctors-areview-from-mainland-china-20082016-12601.html

Martínez-Lanz, P., Medina-Mora, M. E., \& Rivera, E. (2005). Adicciones, depresión y estrés en médicos residentes. Rev Fac Med UNAM, 48(5), 191-197.

Mata, D. A., Ramos, M. A., Bansal, N., Khan, R., Guille, C., Di Angelantonio, E., \& Sen, S. (2015). Prevalence of depression and depressive symptoms among resident physicians: A systematic review and meta-analysis. JAMA, 314(22), 2373-2383. doi: 10.1001/jama.2015.15845

Melo-Carrillo, A., Van Oudenhove, L., \& Lopez-Avila, A. (2012). Depressive symptoms among Mexican medical students: High prevalence and the effect of 
a group psychoeducation intervention. Journal of Affective Disorders, 136(3), 1098-1103. doi: 10.1016/j.jad.2011.10.040

Mingote Adan, J. C., Crespo Hervás, D., Hernández Álvarez, M., Navío, M., \& GarcíaPando, C. R. (2013). Prevención del suicidio en médicos. Medicina y Seguridad del Trabajo, 59(231), 176-204. doi: 10.4321/s0465-546x2013000200002

Nayak, M. S. D. P., \& Narayan, K. A. (2019). Strengths and Weakness of Online Surveys. IOSR Journal of Humanities and Social Science, 24(5), 31-38. doi: 10.9790/0837-2405053138

Olagunju, A. T., Ogundipe, O. A., Lasebikan, V. O., Coker, A. O., \& Asoegwu, C. N. (2016). Pattern of anxiety psychopathology experienced among postgraduate medical trainees. Bangladesh Journal of Medical Science, 15(1), 25-32. doi: 10.3329/bjms.v15i1.20497

Prieto-Miranda, S. E., Jiménez-Bernardino, C. A., Cázares-Ramírez G, Vera-Haro, M, J., \& Esparza-Pérez, R. I. (2015). Workdays and their impact on medical residents in a second-level hospital. Medicina Interna de México, 31(6), 669679.

Quince, T. A., Wood, D. F., Parker, R. A., \& Benson, J. (2012). Prevalence and persistence of depression among undergraduate medical students: a longitudinal study at one UK medical school. BMJ Open, 2(4), e001519. doi: 10.1136/ bmjopen-2012-001519

Reséndiz Escobar, E., Bustos Gamino, M. N., Mujica Salazar, R., Soto Hernández, I. S., Cañas Martínez, V., Fleiz Bautista, C., ... Villatoro Velázquez, J. A. (2018). National trends in alcohol consumption in Mexico: results of the National Survey on Drug, Alcohol and Tobacco Consumption 2016-2017. Salud Mental, 41(1), 7-15. doi: 10.17711/SM.0185-3325.2018.003

Romo-Nava, F., Bobadilla-Espinosa, R. I., Tafoya, S. A., Guízar-Sánchez, D. P., Gutiérrez, J. R., Carriedo, P., \& Heinze, G. (2019). Major depressive disorder in Mexican medical students and associated factors: A focus on current and past abuse experiences. Journal of Affective Disorders, 245, 834-840. doi: 10.1016/j. jad.2018.11.083

Santana-Campas, M. A., \& Santoyo Telles, F. (2018). Propiedades psicométricas de la escala riesgo suicida de Plutchik en una muestra de jóvenes mexicanos privados de la libertad. Avances en Psicología, 26(1), 57-64. doi: 10.33539/ avpsicol.2018.v26n2.1127

Schwenk, T. L., Davis, L., \& Wimsatt, L. A. (2010). Depression, stigma, and suicidal ideation in medical students. JAMA, 304(11), 1181-1190. doi: 10.1001/ jama.2010.1300

Shanafelt, T. D., Sinsky, C., Dyrbye, L. N., Trockel, M., \& West, C. P. (2019). Burnout among physicians compared with individuals with a professional or doctoral degree in a field outside of medicine. Mayo Clinic Proceedings, 94(3), 549-551. doi: 10.1016/j.mayocp.2018.11.035

Steel, Z., Marnane, C., Iranpour, C., Chey, T., Jackson, J. W., Patel, V., \& Silove, D. (2014). The global prevalence of common mental disorders: a systematic review and meta-analysis 1980-2013. International Journal of Epidemiology, 43(2), 476-493. doi: 10.1093/ije/dyu038

Tiburcio Sainz, M., Rosete-Mohedano, M. G., Natera Rey, G., Martínez Vélez, N. A., Carreño García, S., \& Pérez Cisneros, D. (2016). Validity and Reliability of the Alcohol, Smoking, and Substance Involvement Screening Test (ASSIST) in University Students. Adicciones, 28(1), 19-27. doi: 10.20882/adicciones.786

van der Heijden, F., Dillingh, G., Bakker, A., \& Prins, J. (2008). Suicidal thoughts among medical residents with burnout. Archives of Suicide Research, 12(4), 344-346. doi: 10.1080/13811110802325349

Veldenz, H. C., Scott, K. K., Dennis, J. W., Tepas, J. J. 3rd., \& Schinco, M. S. (2003). Impaired residents: identification and intervention. Current Surgery, 60(2), 214217. doi: 10.1016/S0149-7944(02)00780-8

Wang, W., Ren, H., Tian, Q., Tang, C., \& Meng, W. (2019). Effects of Occupational Stress on Blood Lipids, Blood Sugar and Immune Function of Doctors. Iranian Journal of Public Health, 48(5), 825-833.

White, A., Shiralkar, P., Hassan, T., Galbraith, N., \& Callaghan, R. (2006). Barriers to mental healthcare for psychiatrists. Psychiatric Bulletin, 30(10), 382-384. doi: $10.1192 / \mathrm{pb} .30 .10 .382$

\section{APPENDIX}

Questions related to discrimination, physical violence, workplace/academic harassment and/or sexual harassment by peers and/or superiors

\begin{tabular}{|c|c|c|}
\hline \multicolumn{3}{|l|}{ 1. En mi formación como residente, considero que ser HOMBRE: } \\
\hline Me da ventajas & (Sí) & (No) \\
\hline Es indiferente & (Sí) & (No) \\
\hline Me da desventajas & (Sí) & (No) \\
\hline \multicolumn{3}{|l|}{ 2. En mi formación como residente, considero que ser MUJER: } \\
\hline Me da ventajas & (Sí) & (No) \\
\hline Es indiferente & (Sí) & (No) \\
\hline Me da desventajas & (Sí) & (No) \\
\hline \multicolumn{3}{|l|}{$\begin{array}{l}\text { 3. En mi formación como residente, considero que ser } \\
\text { TRANSGENERO/TRANSEXUAL: }\end{array}$} \\
\hline Me da ventajas & (Sí) & (No) \\
\hline Es indiferente & (Sí) & (No) \\
\hline Me da desventajas & (Sí) & (No) \\
\hline \multicolumn{3}{|c|}{ Durante el último año, en el espacio donde realizas actualmente tu residencia } \\
\hline \multicolumn{3}{|l|}{ 1. Por parte de tus compañeros(as) residentes: } \\
\hline a) ¿Sufriste alguna forma de discriminación? & (Sí) & (No) \\
\hline b) ¿Fuiste objeto de violencia física? & (Sí) & (No) \\
\hline c) ¿Fuiste víctima de acoso laboral o académico? & (Sí) & (No) \\
\hline d) ¿Fuiste víctima de acoso sexual? & (Sí) & (No) \\
\hline \multicolumn{3}{|l|}{ 2. Por parte de tus superiores (autoridades, adscritos, etc.): } \\
\hline a) ¿Sufriste alguna forma de discriminación? & (Sí) & (No) \\
\hline b) ¿Fuiste objeto de violencia física? & (Sí) & (No) \\
\hline c) ¿Fuiste víctima de hostigamiento laboral o académico? & (Sí) & (No) \\
\hline d) ¿Fuiste víctima de hostigamiento sexual? & (Sí) & (No) \\
\hline
\end{tabular}

